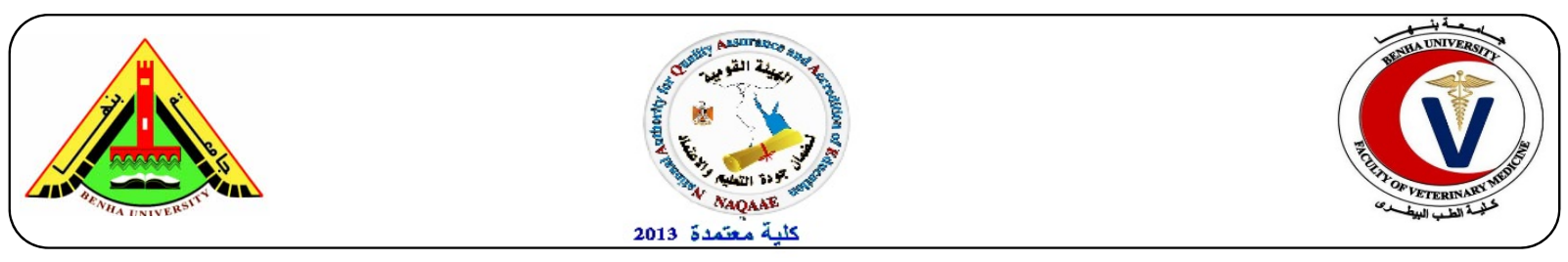

\title{
Detection of SNPs in Exon10 Locus of FSHR Gene and Their Association with Some Infertility problems in Egyptian Buffaloes
}

Basant, M.N. ShafiK ${ }^{1}$; El-Bayomi, Kh. M. ${ }^{2}$; Abo-Salem, M.E.S. ${ }^{3}$; Darwish, S.A. ${ }^{4}$ and Sherif, I. Ramadan. $^{5}$

${ }^{1}$ Animal Wealth Development Dept., Fac. of Vet. Med., Benha Univ.

${ }^{2}$ Animal Wealth Development Dept., Fac. of Vet. Med., Zagazig Univ.

${ }^{3}$ Forensic Medicine Dept., Fac. of Vet. Med., Benha Univ.

${ }^{4}$ Animal Production Research Institute, ARC., Ministry of Agriculture, Doki, Giza, Egypt.

${ }^{5}$ Animal Wealth Development Dept., Fac. of Vet. Med., Benha Univ.

\section{A B S T R A C T}

Follicle-stimulating hormone (FSH) is a glycoprotein hormone. It helps in development and maturation of the follicles in females through binding to FSH receptors which consists of 10 exons and 9 introns. The objective of this study was to estimate some genetic factors affecting milk production and fertility traits and to detect polymorphisms in exon 10 of FSHR gene and determine the associations between these polymorphisms and infertility in Egyptian buffalo. Heritability estimates were $(0.19,0.18,0.07,0.10,0.21$ and 0.19$)$ for calving interval, days open, dry period, days in milk, total milk yield and 305day milk yield (305 DMY), respectively. Dry period showed high positive phenotypic and genetic correlation with day's open and calving interval. The breeding value for 305 DMY ranged from -480 to 380 , from -370 to 330 and between -230 to $170 \mathrm{~kg}$ for cow, sire and dam, respectively. There was one non synonymous SNP (A93G) at 93bp in exon 10 of FSHR gene (with 230bp size) and there was two different pattern of single strand conformation polymorphism (SSCP) but there was no any SNP for FSHR gene (with 306bp size) in all examined Egyptian buffaloes as shown by one SSCP pattern and nucleotide sequencing.

Keywords: correlation. Egyptian buffaloes. FSHR. heritability. Polymorphism. SNP. SSCP.

(http://www.bvmj.bu.edu.eg)

(BVMJ-32(1): 160-169, 2017)

\section{INTRODUCTION}

River buffaloes are the main source of meat and milk production in Egypt so it considers of a great economic value. Genetic improvement of productive traits of buffaloes has been dependent on some information of quantitative genetics of various traits of economic importance to make efficient and easy selection of Egyptian buffaloes (Kumar et al., 2009). Anestrous due to ovarian dysfunction and silent heat also repeat breeding are two major reproductive disorders in buffaloes (Goley and Kadu, 1995). The major cause for low productivity in buffalo is poor reproductive efficiency that is caused by delayed maturity, silent estrous, poor expression of estrous, anestrous and irregular estrous cycle (Sana et al., 2014). Reproductive efficiency has high priority in all breeding systems and for its understanding need more studies especially in poor and seasonal breeder animals. Genetics is the main way for the selection of superior animals that can transmit their favorable traits to their progeny (Emtenan et al., 2014). The endocrine system is the most regulators of the reproductive functions of the body through interactions between the hypothalamus, pituitary gland and gonad. The Follicle Stimulating Hormone Receptor (FSHR) gene is expressed in the gonads. The actions of Follicle Stimulating Hormone (FSH) on ovarian and testicular somatic cells through binding with these receptors (Themmen and Huhtaniemi, 2000). FSH is fundamental for sertoli cell function which stimulate spermatogenesis and growth of the follicles by binding with its specific receptor (FSHR) (Zalata et al., 2008).

The objective of this study was: A. Estimation of some genetic parameters as heritability, genetic and phenotypic correlations among some traits and estimate expected breeding values. B. 
Identification of polymorphisms in the candidate gene (FSHR) associated with some reproductive problems in Egyptian buffaloes.

\section{MATERIAL AND METHODS}

The data used in the present study were collected from the productive and reproductive records of Egyptian buffaloes maintained at Mahalet-Mousa experimental farms of Animal Production Research Institute (APRI), Agricultural Research Centre, Ministry of Agriculture. By rectal examination and ultrasonography, animals were divided into three groups: animals were cyclic, animals having anoestrous (due to ovarian inactivity) and animals which had more than three services (repeat breeder animals).

\subsection{DNA extraction:}

Under investigation, blood samples were taken from 60 selected animals from jugular veins in EDTA- containing vacutainer tubes, kept in ice box and stored at stored at $-20^{\circ} \mathrm{c}$ till further processing. The genomic DNA was extracted from the whole blood by using TIANamp Genomic DNA Kit (www.tiangen.com/en). The concentration of DNA was measured by using Nanodrop. The experiments were carried out at Central Lab, Faculty of Veterinary Medicine, Benha University, Egypt.

\subsection{Polymerase chain reaction (PCR):}

The Exon 10 of FSHR locus was amplified by PCR using primers (Table 1). PCR was performed by employing a PCR program as follows: - Initial denaturation step at $94^{\circ} \mathrm{C}$ for $5 \mathrm{~min}$, then tubes were subjected to 30 cycles of $94^{\circ} \mathrm{C}$ for $1 \mathrm{~min}, 57^{\circ} \mathrm{C}$ for 2 min and $72^{\circ} \mathrm{C}$ for 2 min for FSHR (with size 230bp), $62^{\circ} \mathrm{C}$ for $1 \mathrm{~min}$ and $72^{\circ} \mathrm{C}$ for $1 \mathrm{~min}$ for FSHR (with size $306 \mathrm{bp}$ ) followed by a final extension step at $72^{\circ} \mathrm{C}$ for $10 \mathrm{~min}$. Then PCR products were resolved by electrophoresis and stained with ethidium bromide and visualized with UV light of Gel Documentation System.

\subsection{Single Strand Conformation Polymorphism (SSCP):}

$5 \mu \mathrm{L}$ PCR products were mixed well with $5 \mu \mathrm{l}$ formamide loading dye then heated in thermal cycler for 10 minutes at $98^{\circ} \mathrm{C}$ then chilled on ice. This product loaded on non-denaturing 10\% polyacrylamide gel and electrophoresis was performed in $1 \times \mathrm{TBE}$ buffer at $150 \mathrm{~V}$ for 90 minutes. After electrophoresis: gel was immersed in a tray filled with $250 \mathrm{ml}$ of ethidium bromide $(25$ $\mu \mathrm{g} / 500 \mathrm{ml}$ in $1 \mathrm{x} \mathrm{TBE}$ ) for 20 minutes then transferred gently in $200 \mathrm{ml}$ of distilled deionized water for de-staining for 5 minutes and finally he fragments patterns were photographed by the gel documentation system (UVDI Major Science, USA).

\subsection{DNA Sequencing:}

After getting purified PCR products with expected size by using PCR purification Zymoclean $^{\mathrm{TM}}$ Gel DNA Recovery Kit to remove primers, primer dimmers, salt, proteins, ethidium bromide and agarose. The sequencing was done by using forward primer in 3500 Genetic Analyzers (Applied Biosystems ${ }^{\circledR}$ ). BLAST software (http://www.ncbi.nlm.nih.gov/) was used for sequence identification and confirmation. The MEGA 6 (Kumar et al., 2008), Finch TV 1.4.0 (http://www.geospiza.com/finchtv/) and Bioedit 7.0.5.3 (Hall, 1999) software were used for sequences alignment and polymorphism detection.

\subsection{Statistical Data Analysis:}

\subsubsection{Heritability, Genetic correlation and breeding value:}

Heritability, genetic correlation and breeding value of studied traits were estimated with derivative free restricted maximum likelihood (DFREML) procedures using (MTDFREMAL) program of (Boldman et al., 1995). The assumed model was: $Y=X b+Z a+e$ Where: $-\mathrm{Y}$ : is the vector of the observed trait, $X$ : is the incidence matrix of fixed effects, $b$ : is the vector of fixed effects, $Z$ : is the incidence matrix of random animal effects, a: is the vector of random animal effects and e: is the vector of random residual effects.

\subsubsection{Phenotypic correlation:}

The phenotypic correlation between traits $\mathrm{x}$ and $\mathrm{y}$ is calculated by SAS (SAS, 2001).

\subsubsection{Gene and Genotypic frequencies:}

Gene and genotype frequencies of FSHR gene (with size 230bp) SNP in buffalo calculated by applying the $\chi^{2}$ test. $\mathrm{P}^{2}+2 \mathrm{pq}+\mathrm{q}^{2}=1 \quad$ (Snedecor and Cochran, 1976).

\section{RESULTS}

Table (2) showed that days in milk, calving interval and days open, total milk yield and 305day milk yield had a moderate heritability estimates. High heritability estimates were for age at first service and calving. Age at first service showed negative phenotypic correlation with other traits except age at first calving. Dry period showed high 
positive phenotypic and genetic correlation with day's open and calving interval Table (3).

Table (4) mentioned the estimated breeding values of sire, dam and cow. Expected breeding value average of 305 day milk yield, calving interval and age at first service was higher in dam. While, Expected breeding value average of dry period and age at first calving was higher in cow. Moreover, expected breeding value average of days open, days in milk and total milk yield was higher in sire

The PCR product with the expected size (230bp and 306bp) for exon 10 of FSHR gene was observed on agarose gel electrophoresis (Figure 1 and 2). There is one non synonymous SNP (A93G) at $93 \mathrm{bp}$ (Figure 6) and led to change of methionine amino acid into isoluocine amino acid in exon 10 of FSHR gene (with 230bp size) which identified by PCR-SSCP and sequencing in female Egyptian water buffaloes. There was two different pattern of PCR-SSCP for this gene (Figure 3). Nucleotide sequences alignment of FSHR gene showed 98\% identity with Bubalus bubalis (EU148059.1) (Figure 7).

In exon 10 of FSHR gene (with size 306bp), there was no any SNP in all examined Egyptian buffaloes by sequencing (Figure 8) which shown by only one pattern SSCP (Figure 4). Nucleotide sequences alignment of FSHR gene showed 96\% identity with Bubalus bubalis (EF560049.1) (Figure 9).

Table (1): Primer Information for Analysis:

\begin{tabular}{llll}
\hline Gene & \multicolumn{1}{c}{ Primer sequences $\left(5^{\prime}-3^{\prime}\right)$} & PCR product & Reference \\
\hline FSHR & F: ATCACGCTGGAAAGATGGCATACC & 230 bp & (Yong et al., 2006) \\
& R: GACATTGAGCACAAG GAGGGA C & & \\
FSHR & F: CTGCCTCCCTCAAGGTGCCCCTC & 306 bp & (Othman and Abdel-Samad, 2013) \\
& R: AGTTCTTGGCTAAATGTCTTAGGGGG & & \\
\hline
\end{tabular}

Table (2): Heritability Estimates among Different Studied Milk Production and Fertility Traits.

\begin{tabular}{ll}
\hline Trait & $\mathrm{h}^{2} \pm \mathrm{S} . \mathrm{E}$ \\
\hline AFS & $1.00 \pm 0.093(\mathrm{O} . \mathrm{E})$ \\
AFC & $0.98 \pm 0.001(\mathrm{O} . \mathrm{E})$ \\
CI & $0.19 \pm 0.036$ \\
DO & $0.18 \pm 0.036$ \\
DP & $0.07 \pm 0.037$ \\
DIM & $0.10 \pm 0.028$ \\
TMY & $0.21 \pm 0.035$ \\
305 DMY & $0.19 \pm 0.035$ \\
\hline
\end{tabular}

Table (3): Phenotypic (above the diagonal) and Genetic Correlations (below the diagonal) among Different Milk Production and Fertility Traits.

\begin{tabular}{lllllllll}
\hline Trait & AFS & AFC & CI & DO & DP & DIM & TMY & 305 DMY \\
\hline AFS & - & $0.02^{* *}$ & -0.03 & -0.02 & -0.05 & -0.02 & -0.01 & -0.03 \\
AFC & 0.02 & - & $0.09^{* *}$ & $0.10^{* *}$ & 0.06 & -0.06 & $-0.11^{* *}$ & -0.06 \\
CI & -0.17 & -0.23 & - & $0.97^{* *}$ & $0.88^{* *}$ & -0.007 & 0.004 & 0.02 \\
\multicolumn{1}{c}{ DO } & 0.01 & -0.03 & 1.00 & - & $0.86^{* *}$ & -0.008 & 0.008 & 0.03 \\
DP & 0.05 & 0.04 & 0.96 & 0.97 & - & -0.05 & $-0.09^{*}$ & -0.03 \\
DIM & 0.67 & -0.13 & 0.56 & 0.55 & -0.50 & - & $0.46^{* *}$ & $-0.15^{* *}$ \\
TMY & 0.07 & -0.22 & 0.38 & 0.29 & -0.23 & 0.73 & - & $0.69^{* *}$ \\
305DMY & 0.09 & -0.13 & 0.18 & 0.25 & 0.16 & 0.29 & 0.86 & - \\
\hline
\end{tabular}


Table (4): Breeding Value Estimates for Different Studied Milk Production Traits and Fertility Traits for Cow, Sire and Dam.

\begin{tabular}{|c|c|c|c|c|c|c|c|c|c|}
\hline \multirow{3}{*}{ Trait } & \multicolumn{9}{|c|}{ Estimated Breeding Value } \\
\hline & \multicolumn{3}{|l|}{ Cow } & \multicolumn{3}{|l|}{ Sire } & \multicolumn{3}{|l|}{ Dam } \\
\hline & Min & Max & Average & Min & Max & Average & Min & Max & Average \\
\hline AFS & -7.05 & 11.95 & -0.36 & -4.7 & 5.6 & -0.26 & -3.8 & 7.2 & -0.1 \\
\hline $\mathrm{AFC}$ & -15.8 & 25.2 & 0.26 & -7.9 & 11.4 & 0.12 & -7.9 & 16.5 & 0.07 \\
\hline CI & -1.6 & 3.7 & -0.01 & -0.9 & 1.9 & 0.004 & -1.5 & 2.4 & 0.002 \\
\hline DO & -43.1 & 97.9 & -0.21 & -41.9 & 76.3 & 0.08 & -29.4 & 51.8 & 0.05 \\
\hline DP & -24 & 44.9 & 0.07 & -15.4 & 22.5 & -0.12 & -17.6 & 22.5 & 0.02 \\
\hline DIM & -20.2 & 32.8 & -0.51 & -12.3 & 18.3 & 0.15 & -10.6 & 15.8 & 0.03 \\
\hline TMY & -380 & 370 & -10 & -310 & 240 & 2 & -160 & 180 & 0.5 \\
\hline 305DMY & -480 & 330 & -20 & -370 & 330 & -0.4 & -230 & 170 & 0.1 \\
\hline
\end{tabular}

Figure (1): Stained agarose gel of PCR products with Eethidium bromide representing amplification of FSHR gene (exon10) with size of $230 \mathrm{bp}$ (lanes1-6) in Egyptian buffaloes. M represents 100 bp ladder.

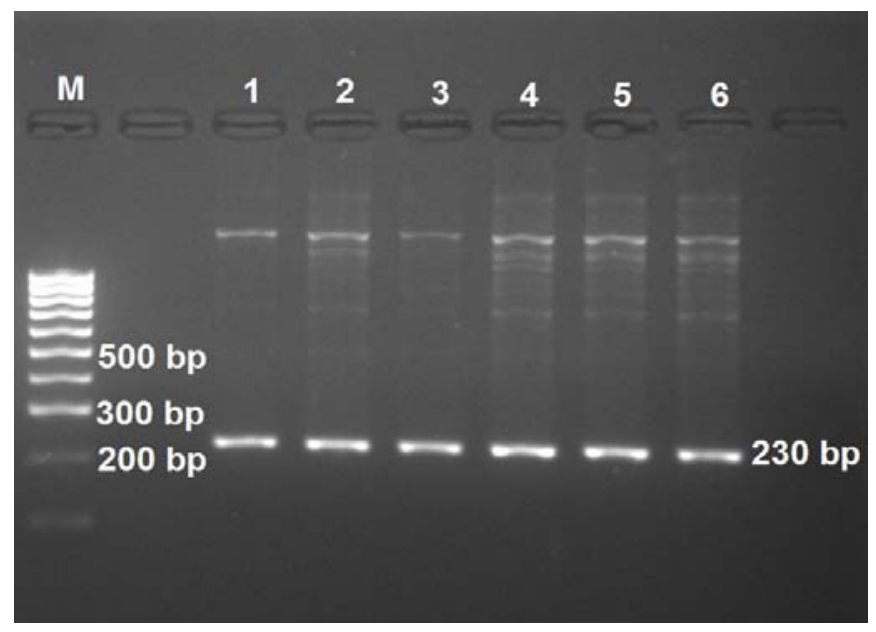

Figure (2): Stained agarose gel of PCR products with ethidium bromide representing amplification of FSHR gene (exon10) with size of 306 bp (lanes1-6) in Egyptian buffaloes. M represents 100 bp ladder.

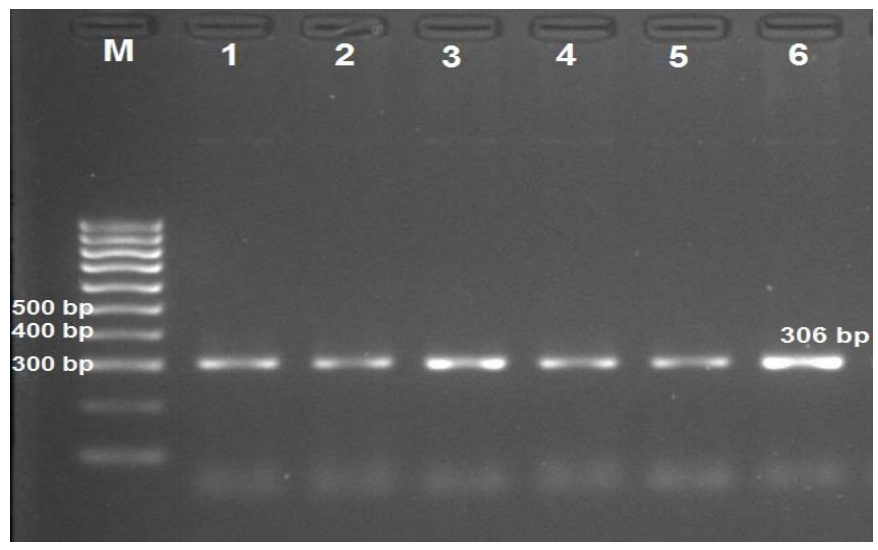


Figure (3): PCR-SSCP patterns of FSHR gene exon 10 with size 230 bp in Egyptian buffaloes. Two SSCP patterns were detected in FSHR gene; genotype GG (lane 1-6) and genotype AG (lane 7).

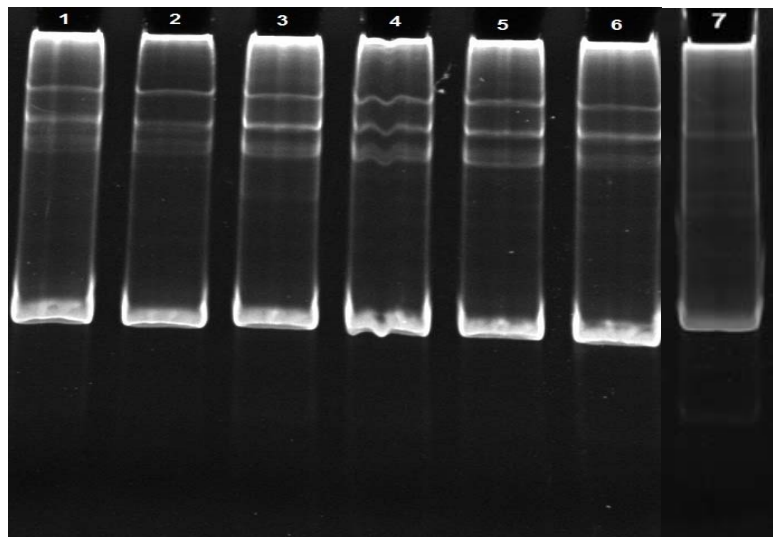

Figure (4): PCR-SSCP patterns of FSHR gene exon 10 with size 306 bp in Egyptian buffaloes. One PCRSSCP pattern (monomorphic) was showed.

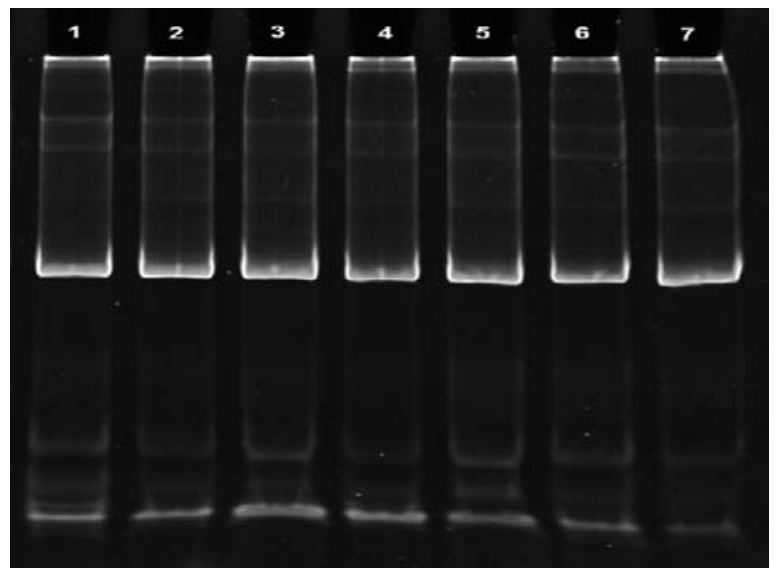

Figure (5): Nucleotide sequences of FSHR in Egyptian water buffaloes showed A93G SNP at nucleotide number 93 of exon 10 (with size 230bp).

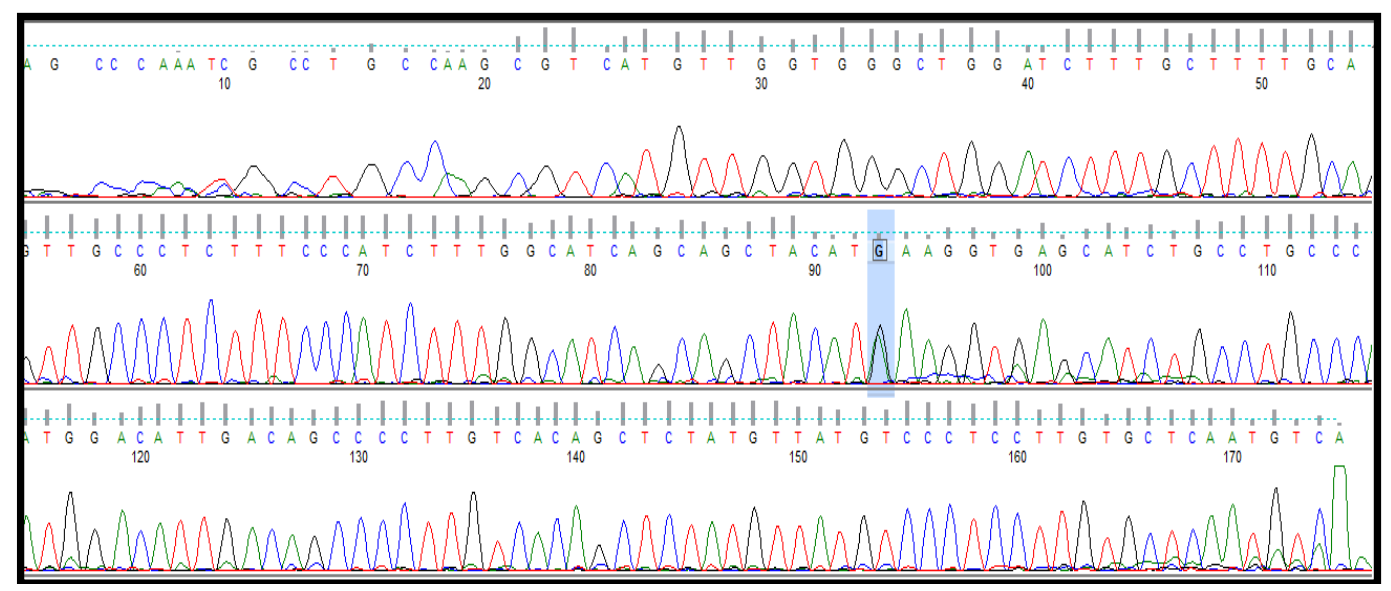


Figure (6): The sequence of FSHR gene exon 10 (with size 230bp) showed one non synonymous SNP (A93G).

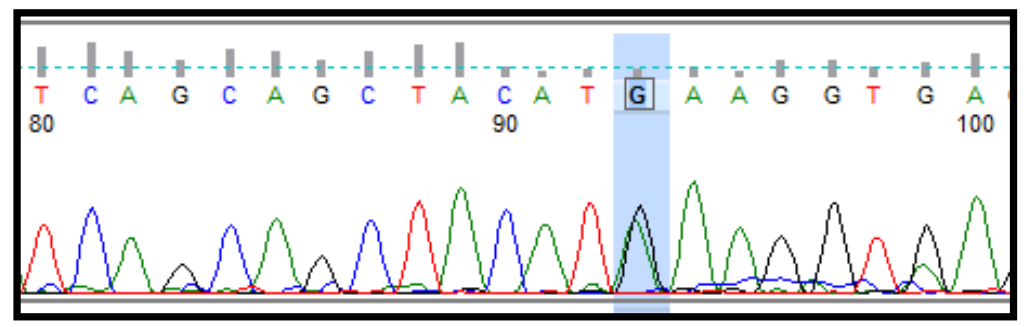

Figure (7): Nucleotide sequences alignment of FSHR (exon10) with size 230 bp using BLAST with Bubalus bubalis FSHR (exon10) (EU148059.1) showed 98\% identity.

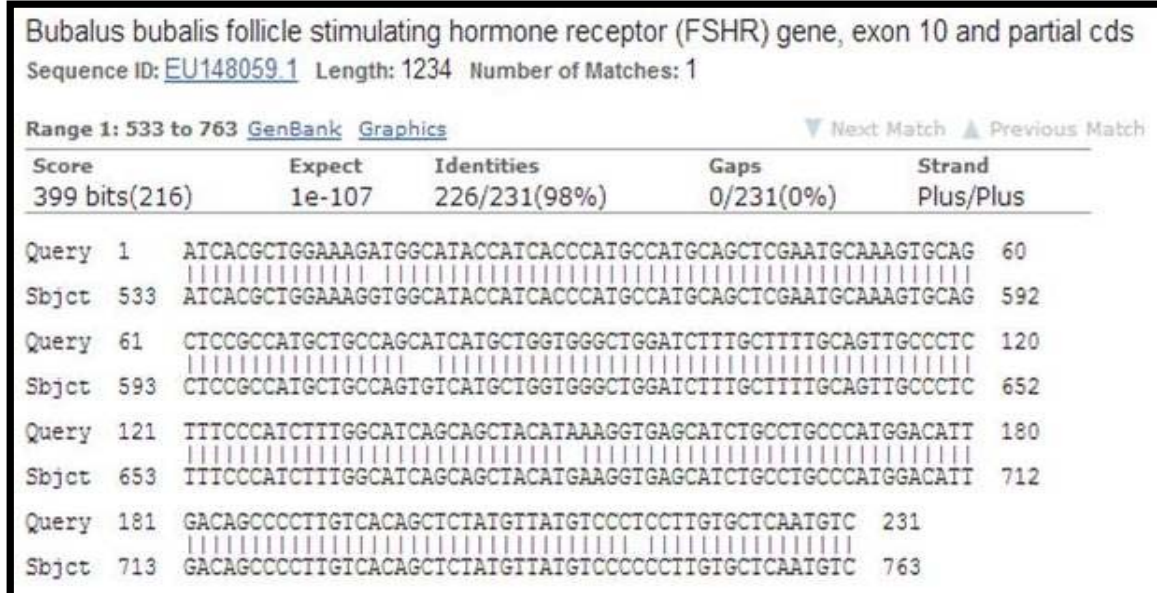

Table (4): Genotype and allelic frequencies at A93G SNP of buffalo FSHR gene and estimated by Chi-Square $(\chi 2)$ test.

\begin{tabular}{lllllll}
\hline SNP & \multicolumn{2}{l}{ Genotype frequencies } & & \multicolumn{2}{l}{ Allele frequencies } & $P$ value \\
\hline \multirow{2}{*}{ A93G } & AA & AG & GG & A & G & \multirow{2}{*}{0.9317} \\
& $0.02 \%$ & $2.82 \%$ & $97.16 \%$ & $1.43 \%$ & $98.57 \%$ & \\
\hline
\end{tabular}

Figure (8): Nucleotide sequences of FSHR exon 10 (with 306bp) in Egyptian water buffaloes showed no polymorphism.

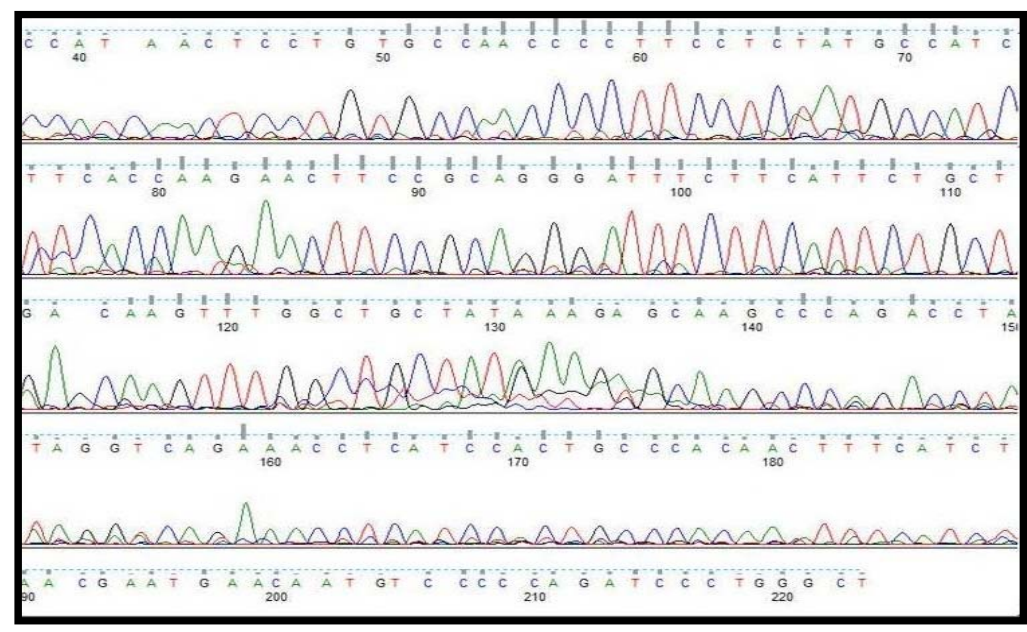


Figure (9): Nucleotide sequences alignment of FSHR (exon10) with size 306 bp using BLAST with Bubalus bubalis FSHR (exon10) (EF560049.1) showed 96\% identity.

\begin{tabular}{|c|c|c|c|c|c|c|}
\hline \multicolumn{7}{|c|}{$\begin{array}{l}\text { Bubalus bubalis follicle stimulating ho } \\
\text { Sequence ID: EF } 650049.1 \text { Length: } 1233 \mathrm{~m} \\
\text { Range 1: } 926 \text { to } 1231 \text { GenEank Graphics }\end{array}$} \\
\hline \multicolumn{2}{|c|}{$\begin{array}{l}\text { Score } \\
505 \text { bits (273) }\end{array}$} & $\begin{array}{l}\text { Expect } \\
3 e-139\end{array}$ & $\begin{array}{l}\text { Identities } \\
295 / 306(96 \%)\end{array}$ & $\begin{array}{l}\text { Gaps } \\
0 / 306(0 \%)\end{array}$ & \multicolumn{2}{|c|}{$\begin{array}{l}\text { Strand } \\
\text { Plus/Plus }\end{array}$} \\
\hline Query & 1 & C. & & & I & 60 \\
\hline Sbjet & 926 & $\operatorname{ctc}$ & CICAT & CAD & CCTAI & 985 \\
\hline Query & 61 & CATCA: & GIGCCAAC & GCCATC: & ACTICC & 120 \\
\hline Sbjet & 986 & CATCA & $\mathrm{GCCZ}$ & CCATCTICA & CTICC & 1045 \\
\hline Query & 121 & & & & & 180 \\
\hline Sbjet & 1046 & IITC1 & A & TAIGA & AGACCI & 1105 \\
\hline Query & 181 & AGAAAC & 1 & th & $\operatorname{rcccc}$ & 240 \\
\hline $\mathrm{Sbjct}$ & 1106 & ATAGGTCAGAAAC & CCACTGC & & $\operatorname{ccccc}$ & 1165 \\
\hline Query & 241 & CTGG & GIGGITC: & & CCA & 300 \\
\hline Sbjet & 1166 & $A G G G$ & Grogliced & & & 1225 \\
\hline Query & 301 & 306 & & & & \\
\hline Sbjct & 1226 & AGAACI 1231 & & & & \\
\hline
\end{tabular}

\section{DISCUSSION}

A low heritability estimate was 0.07 for dry period. The low heritability estimates were found in dry period indicated that the major part of the variation may be due to non-genetic factors and better management could play a good role in improving this trait. These results agreed with (Sujit and Sadana, 2000) and (Thevamanoharan et al., 2002). On the contrary to the present findings (Aziz et al., 2001), (Kawthar et al., 2005), (Thiruvenkadan et al., 2010) and (Shalaby et al., 2013) who showed moderate heritability estimates for dry period. A moderate heritability estimates was $0.10,0.21$ and 0.19 for lactation length, total milk yield and 305 day milk yield, respectively. The obtained results were in the same line of those obtained by (Thevamanoharan et al., 2002), (Mourad and Khattab, 2009), (El-Bramony, 2011), (Malhado et al., 2013) and (El-Bramony, 2014). On the contrary to the present findings (Kawthar et al., 2005), (EL-Arian et al., 2012) and (Ibrahim et al., 2012) showed high heritability for days in milk and milk yield. Moderate heritability estimate was 0.18 and 0.19 for days open and calving interval, respectively. These results agreed with (Amin and Alhur, 2011) and (El-Bramony, 2014). The opposite results obtained by (Aziz et al., 2001), (Thevamanoharan et al., 2002), (Badran et al., 2005), (Kawthar et al., 2005), (El-Bramony, 2011), (Malhado et al., 2013) and (Barros et al., 2016) who recorded low heritability estimates for days open and calving interval.

Calving interval had high positive phenotypic correlation with days open (0.97) and dry period (0.88). Moreover, there were low positive correlations with total milk yield (0.004). These results were in consistence with the findings obtained by (Aziz et al., 2001) and (Badran et al., 2005) showed high positive phenotypic correlation of calving interval with days open. Also, (Ramos et al., 2006) and (Malhado et al., 2013) recorded low positive correlation of calving interval with milk yield. There was high positive phenotypic correlation of days open with dry period $(0.86)$. Moderate positive phenotypic correlation was found among days in milk and total milk yield (0.46). These results agreed with (Shalaby et al., 2013) reported that positive phenotypic correlation among days in milk and total milk yield. High positive genetic correlation was recorded between calving interval with each of days open (1.00), dry period (0.96) and days in milk (0.56). The obtained results were in the same line of those obtained by (Badran et al., 2005). On the contrary, opposite results obtained by (Aziz et al., 2001). There was high positive genetic correlation between days open with each of dry period (0.97) and days in milk (0.55) but low positive correlation with total milk yield (0.29) and 305day milk yield (0.25). These results disagreed with those reported by (Aziz et al., 2001). High positive genetic correlation between total milk yield with each of days in milk (0.73) and 305day milk yield (0.86). Similar to present results (Mourad and Khattab, 2009), (Ibrahim et al., 2012), (EL-Arian et al., 2012) and (Shalaby et al., 2013) recorded that high positive genetic correlation between days in milk and milk yield. The opposite results obtained by (Barros et al., 2016) reported that low negative correlation between days in milk and milk yield. 
The breeding value for total milk yield and 305day milk yield of cows ranged between -380 and 370 and between -480 and $380 \mathrm{~kg}$, respectively. Moreover, values for sires were between -310 and 240 and between -370 and 330 $\mathrm{kg}$, respectively. While the corresponding values for dams were between -160 and 180 and between -230 and $170 \mathrm{~kg}$, respectively. The opposite results obtained by (Cady et al., 1983) who found that expected breeding values for sires of Nili-Ravi Buffaloes for 250 to 305 day milk yield averaged from $-172 \mathrm{~kg}$ to +260 , (EL-Arian et al., 2012), (Ismail, 2006), (Fooda et al., 2011) who showed that breeding value estimates for total milk yield was ranged between +101 to $-269 \mathrm{~kg}$ for Egyptian buffaloes.

There is one non synonymous SNP (A93G) at 93bp and led to change of methionine amino acid into isoluocine amino acid in exon 10 of FSHR gene (with 230bp size). The opposite results obtained by (Lan et al., 2006) showed that there was no mutation in exon 10 of FSHR gene with $230 \mathrm{bp}$ in Haimen goat. Also, there was no polymorphism of exon 10 of FSHR gene (with size $230 \mathrm{bp}$ ) detected in goat and this gene had only one genotype so this locus was homozygous by PCRSSCP (Lei et al., 2010) and (Li et al., 2010). There was no polymorphism of exon 10 of FSHR gene (with size $306 \mathrm{bp}$ ) detected in Egyptian buffaloes which shown by only one pattern by PCR-SSCP. The obtained results were in the same line of those obtained by (Othman and Abdel-Samad, 2013) and (Sosa et al., 2015) showed that the PCR product for FSHR gene gave the specific band at size $306 \mathrm{bp}$ and all examined buffaloes were genotyped as CC and there was none SNP in this gene by sequencing. The opposite results obtained by (Marson et al., 2008) observed that there were three genotype for FSHR gene (GG, CG and CC) in European-Zebu composite beef heifers from six different breed compositions by digestion with AluI restriction endonuclease Also, (Ahmed et al., 2011) who reported that there was polymorphism in FSHR gene locus with size 306bp by SSCP.

\section{REFERENCES}

Ahmed, S.S., Abdel aziz, K.B., Hassan, N.A., Mabrouk, D.M., 2011. Genetic polymorphism of some genes related to reproductive traits and their association with calving interval in Egyptian buffalo. Genomics Quantitative Genetics 1, 1-8.

Amin, A.A., Alhur, F.S., 2011. Genetic influnce of lactation length on reproductive performance of Egyptian buffaloes.
Scientific Journal of King Faisal University. Basic and Applied Sciences 12(1) Abstract.

Aziz, M.A., Schoeman, S.J., Jordaan, G.F., O.M., E.-C., Mahdy, A.T., 2001. Genetic and phenotypic variation of some reproductive traits in Egyptian buffalo. South African Journal of Animal Science 31(3), 195-199.

Badran, A.E., El-Barbary, A., Bedeir, L., Shafie, O.M., 2005. Inbreeding and reproductive performance in Egyptian buffaloes. Buffalo Journal 21(2), 183-188.

Barros, C.C., Borquis, R.R.A., Fraga, A.B., Tonhati, H., 2016. Genetic parameter estimates for production and reproduction traits in dairy buffaloes. Rev. Caatinga, Mossoró 29(1), 216 - 221.

Boldman, K.G., Kriese, L.A., Van Vleck, L.D., Van Tassell, C.P., Kachman, S.D., 1995. A manual for use of MTDFRML. Department of Agriculture / Agriculture Research Service, Lincolin, USDA, Washington DC, USA.

Cady, R.A., Shah, S.K., Schermerhorn, E.C., Mcdowell, R.E., 1983. Factors affecting performance of Nili-Ravi buffaloes in Pakistan. Journal of Dairy Science 66, 578586.

EL-Arian, M.N., Shalaby , N.A., Khattab, A.S., Darwish, S.A., Abou-Gamous, S.A., 2012. Phenotypic and genetic trends for some milk yield traits of Egyptian buffaloes J. Animal and Poultry Prod., Mansoura Univ. 3(7), 353 - 364.

El-Bramony, M.M., 2011. Genetic and phenotypic parameters of milk yield and reproductive performance in the first three lactations of egyptian buffalo. Egyptian J. Anim. Prod 48(1), 1-10.

El-Bramony, M.M., 2014. Estimation of genetic and phenotypic parameters for milk yield, lactation length, calving interval and body weight in the first lactation of Egyptian buffalo. Life Science Journal 11(12), 10121019.

Emtenan, M.H., Ahmed, W.M., Zaabal, M.M., El khadrawy, H.H., 2014. Genomics control of folliculogenesis in animals with emphasis to buffaloes. Global Veterinarian 13(5), 680689.

Fooda, T.A., Elbeltagy , A.R., Hassan, L.R., Awad., S.E.-h.S., 2011. Assessment of Egyptian buffaloes crossing with Pakistani and Italian buffaloes for some production traits. Journal of American Science 7(1), 269-279. 
Goley, R.R., Kadu, M.S., 1995. Efficacy of PGF2 $\alpha$ (Lutalyse), GnRH analogue (Receptal) a d HCG (Chorulon) in treatment of repeat breeding cows. Indian Vet. J. 72, 472-475.

Hall, T.A., 1999. Bio Edit: a user-friendly biological sequence alignment editor and analysis program for Windows 95/98/NT. Nucleic Acids Symposium Series 41, 95-98.

Ibrahim, M.A., Khattab, A.S., Set El- Habaeib, S.A., T1zsér, J., 2012. Genetic parameters for buffalo milk yield and milk quality traits using animal model. AWETH 8(2), 175-182.

Ismail, H., 2006. Phenotypic and Genetic parameters of milk production and reproductive performance of Holstein cattleunder the intensive production system in Egypt. (Personal communication).

Kawthar, A.M., Fooda, T.A., Karima, A.S., Ashmawy, A.A., 2005. Lactation curve, milk production and days open of Egyptian buffaloes. Bubalus Bubalis 11(1), 72-80.

Kumar, O.S., Sharma, D., Singh, D., Sharma, M.K., 2009. CYP19 (cytochrome P450 aromatase) gene polymorphism in Murrah buffalo heifers of different fertility performance. Vet. Sci. 86, 427-437.

Kumar, S., Nei, M., Dudley, J., Tamura, K., 2008. MEGA: A biologist-centric software for evolutionary analysis of DNA and protein sequences. . Briefings in Bioinformatics 9, 299-306.

Lan, Y.X., Chen, H., Chen, C.Y., Pan, C.Y., Lei, C.Z., Zhang, Y.D., Yu, J., 2006. PCR-SSCP detection and DNA sequence analysis of exon 10 of goat Follicle-Stimulating Hormone Receptor (FSHR) gene. J. Agric. Biotechnol 14, 484-488.

Lei, H., Dong, Z.X., Yong, W., Kun, M.X., Wei, X.H., Li, M., San, F.X., Shi-wu, L., 2010. SNP analysis on Follicle-stimulating Hormone Receptor Gene (FSHR) in Lezhi black goats. Journal of Southwest University for Nationalities. Abstract.

Li, Y.J., Zhang, L., Shang, L.Q., Wang, H.F., Zou, H., Zhang, H., Ji, D.J., 2010. Genetic polymorphisms at three loci of PRLR and FSHR gene correlate with litter size in Chinese Haimen Goat. Journal of Animal and Veterinary Advances 9(22), 2835-2838.

Malhado, C.H.M., Malhado, A.C.M., Ramos, A.D.A., Carneiro, P.L.S., Souza, J.C.D., Pala, A., 2013. Genetic parameters for milk yield, lactation length and calving intervals of Murrah buffaloes from Brazil. R. Bras. Zootec 42(8), 565-569.

Marson, E.P., Ferraz, J.B.S., Meirelles, F.V., Balieiro, J.C.C., Eler, J.P., 2008. Effects of polymorphisms of LHR and FSHR genes on sexual precocity in a Bos taurus $x$ Bos indicus beef composite population. Genetics and Molecular Research 7(1), 243-251.

Mourad, K.A., Khattab, A.S., 2009. A comparison between different selection indices for some productive traits on Egyptian buffaloes. Archiv Tierzucht 52, 476-484.

Othman, O.E., Abdel-Samad, M.F., 2013. RFL polymorphism of three fertility genes in Egyptian buffalo. of Applied Biological Sciences 7(2), 94-101.

Ramos, A.A., Malhado, C.H.M., Carneiro, P.L.S., 2006. Caracterização fenotípica e genética da produção de leite e do interval entre partos em bubalinos da Raça Murrah. Pesquisa. Agropecuária Brasileira 41(8), 1261-1267.

Sana, I., Maryam, J., Yaqub, T., Madiha, I., Asif, N., Nadia, M., Fatima, M., 2014. Genetic basis of estrous in bovine: A Review. . International Journal of Advanced Research 2, 962-966.

SAS, 2001. statistical analysis system, User's Guide Computers by SAS Institute Inc., Cary, NC, USA.

Shalaby, N.A., El-Barbary, A.S.A., Oudah, E.Z.M., Helmy, M., 2013. Genetic analysis of some productive and reproductive traits of first lactation of Friesian cattle raised in Egypt. J. Animal and Poultry Prod., Mansoura Univ. 4(2), 97 -106.

Snedecor, G.M., Cochran, W., 1976. Statistical methods, 6th ed. The Iowa State University Press,Ames,IO.

Sosa, A.S.A., Karima, G.M.M., Eldebaky, H.A.A., Kandiel, M.M.M., Abou E 1-Roos, M.E.A., Nawito, M.F., 2015. Genotyping of follicle stimulating hormone receptor gene in fertile and infertile buffalo. Global Veterinaria 15(2), 163-168.

Sujit, S., Sadana, D.K., 2000. Effect of genetic and non-genetic factors on reproductive traits in Murrah buffaloes. Indian Journal of Animal Health 39(1), 41-42.

Themmen, A.P.N., Huhtaniemi, I.T., 2000. Mutations of gonadotropins and gonadotropin receptors: elucidating the physiology and pathophysiology of pituitary-gonadal function. Endocr Rev 21, 551-583.

Thevamanoharan, K., Vandepitte, W., Mohiuddin, G., javed, K., 2002. Animal Model Heritability Estimates for Various Production and Reproduction Traits of NiliRavi Buffaloes. Int. J. Agri. Biol. 4(3), $357-$ 361 . 
Thiruvenkadan, A.K., Panneerselvam, S., Rajendran, R., Murali, N., 2010. Analysis on the productive and reproductive traits of Murrah buffalo cows maintained in the Coastal region of India. South African society for animal science 3, 1-4.

Yong, L., Hong, C., ying, P.C., zhao, L.C., Yong, Z., Jiao, Y., 2006. PCRSSCP detection and DNA sequence analysis of exon 10 of goat
Follicle-Stimulating Hormone Receptor (FSHR) gene. Journal of agricultural biotechnology 14(4), 484-488.

Zalata, A.A., Hassan, A.H., Nada, H.A., Bragais, F.M., Agarwal, A., Mostafa, T., 2008. Follicle-stimulating hormone receptor polymorphism and seminal anti-Mullerian hormone in fertile and infertile men. Andrologia 40, 392-397. 